\title{
A Mufassir \\ Not Just an Interpreter
}

Adewuni Salawu

\begin{abstract}
In most Muslim spiritual gatherings in Southwest Nigeria, as observed today, preaching is in a mixed Yoruba and Arabic languages. The leading preacher or Mufasiru is often compelled to interpret all Arabic words and sentences to the Yoruba crowd, which does not speak, read and write Arabic language. Ajanansi who is like Mufasiru a bilingual (Yoruba and Arabic) assists the latter in his spiritual work. Arowasi is also part of the team of Tafseer but he is not necessarily a bilingual. Ajanansi and Arowasi are invention of Yoruba Muslim circles necessitated by the adaptation of Tafsiri ${ }^{1}$ and Mufassir in Yoruba lands. People often give the trio of Mufasiru, Ajanansi and Arowasi mixed and conflicting meaning of interpreter and commentator. The objective of this study is to clarify the meaning of Mufasiru, Ajanansi and Arowasi. Questionnaires were administered. Data were collated and sorted. A $60 \%$ of the respondents were of the view that Arowasi is an interpreter while 10\% attribute the interpreter status to Mufasiru and Ajanansi. The study concludes that most grassroots Muslim in Southwest Nigeria give wrong meaning to Mufasiru who combines the function of interpreter and Qur'aan commentator.
\end{abstract}

\section{Introduction}

Mufassir is a loanword from Arabic often used in Yoruba Muslim circles of Southwest Nigeria. The word has not only metamorphosed morphologically to Mufasiru ${ }^{2}$ to satisfy the Yoruba standard of pronunciation, it specially has conflicting meanings. Mufasiru, Arowasi and Ajanansi are three different words often 
translated by interpreter. But Arowasi and Ajanansi are composed words necessitated by the adoption and adaptation of Mufassir into the Yoruba vocabulary. Mufasiru, Arowasi and Ajanansi are three different personalities that work for the same purpose, viz the spread and better understanding of Islam in Southwest Nigeria.

\section{Objective of the Study}

The work attempts to clarify the meaning attached to the three words of Mufasiru, Arowasi and Ajanansi as regards its interpretation.

\section{Research Methodology}

A total of 100 questionnaires were distributed to Yoruba Muslims in Southwest Nigeria to seek their views on the appellation and understanding of the three words, Mufasiru, Arowasi, and Ajanansi. Five video cassettes were also viewed to ascertain the functions attributed to the three characters of Mufasiru, Arowasi and Ajanansi.

\section{Contacts with the Arabs}

The trans-Saharan impact on people of West Africa in general and Southwest Nigeria in particular is not negligible and it has spread deep from the towns to the rural villages. Its impact persists in West African life and has greatly affected the orientation and thought of people of the sub-region. At the beginning, Arabs and Berbers were the first and regular business partners of African peoples south of the Sahara. The presence of Europeans in the Bilad-as-Sudan (land of the Blacks) through the Sahara was minimal with Arabs playing the role of middlemen in the exchange of goods and technologies.

The contacts, forceful or peaceful, led to the spread of Islamic

religion and Arab culture. Whatever may be their mission, almost all 
Arabs who found themselves in the land of the Blacks worked directly or indirectly for the spread of Islam and the culture of Arabs. This resulted in the silent Muslim colonization of Sudan.

In fact, before the introduction of Islamic education and the advancement of the Arabic language, the only form of literature available in traditional Africa in the absence of the scriptures was oral literature. The spoken word appeared to have been of primary importance in the traditional African set up (Seymour 1988:170).

In some parts of West Africa people are so acculturated to Islam that they can hardly believe their ancestors had their own culture. Reflecting on the position of Islamic culture in Sudan, Jan Knappert (1970:85) concluded that the influence of Islam and Arabic words on Hausa, Fula, Manding, Swahili and Somali languages was profound with loanwords. These loanwords such as Mufasiru and Tafsiri are also remarkable among Yorubas.

In West Africa today, there is a class of Muslim clerics or Marabouts who are always identified with Islam. They know the Qur'aan and are familiar with the Arab culture. They speak Arabic and are privileged to have advanced instruction in their faith. They also speak their African language. Their principal role is to assist in coordinating Islamic activities such as to be an Imam, Islamic spiritual leader and a Mufassir. Sometimes they play the role of Cadi when necessary. This social class was transposed to West Africa across the Sahara (O’Brien 1971:24-29).

During the reign of Askia Muhammed, the ulama or Islamic teachers multiplied, and became powerful and influential in the state because they were learned people. Arabic was then the official language (Hodgking 1969:362). Cruise O'Brien thus describes the situation in Senegal: 
The marabouts, from an early date, played an important part in the Wolof states as secretaries and advisors to the chiefs. Their ability to read and write was valued increasingly as a means of contacts with neighbouring rulers.

(O’Brien 1971:28)

These ulama persist in all corners of Yoruba lands and some are prominent among them and known as leading preachers or Mufasiru, that is an ulama that masters the spiritual language of Islam, the Arabic and the local language or the language of the converts.

Every mosque is automatically a centre of training and learning. In the medieval era, the historic mosques of Timbuktu and Sankore were centres of excellence during the rule of the Mali and Songhai empires. Generally, the teaching was based on the commentaries of the Qur'aan. Its interpretation (Tafseer) was the order of the day. Grammar constituted a core of the study. Islamic jurisprudence (Fiqh) and the hadiths ${ }^{3}$ of Prophet Muhammad were at the centre of the lectures. This practice is common even today but some open air schools have metamorphosed into more organised institutions affiliated to modern universities. Today, the trio of Mufasiru, Arowasi and Ajanansi have added new dimensions in the spread of Islam by means of preaching in radios, televisions and video cassettes.

\section{Data collation and Discussion}

It all started with observation ${ }^{4}$ during public Muslim spiritual gatherings and in the newspapers where different meanings are attributed to Mufasiru, Arowasi and Ajanansi. In most cases, the trio of Mufasiru, Arowasi and Ajanansi are bilingual that is, they speak and write both Arabic and Yoruba language. They all compliment each other during a tafseer or Nasiat ${ }^{5}$. In recent times, with the advancement in technology the position of Arowasi is being made redundant.

Arowasi is a composed word of Aro and Wasi. Ro means to transmit, while Aro means transmitter. Wasi means preaching. Arowasi 
is the transmitter of preaching. Then, Arowasi was transmitting to the large public or crowd, the preaching of Mufasiru, the leading preacher. Arowasi may not be necessarily a bilingual. He may not know Arabic. He was only there to repeat in Yoruba what Mufasiru is saying in Yoruba. Yet the survey carried out, shows a misconception of the public on the functions of Arowasi. Out of 100 questionnaires, $60 \%$ of the respondents look at Arowasi as interpreter and $70 \%$ as transmitter of the message of the leading preacher (Appendix 1). Some respondents see no difference between Arowasi and Ajanansi perhaps because the two characters sometimes interchange their function. While the function of Arowasi is phasing out gradually, Ajanansi is indispensable for the smooth preaching by Mufasiru.

Ajanansi (from Arabic word Nasu which means narration) commonly used in Yoruba Muslim circles is a composed word of Aja and Nansi. Nansi having metamorphosed from NASU, Aja is a Yoruba prefix, which means the person that brings or adds. He is fully playing the role of Qoori, the Qur' aan reciter. Ajanansi is bilingual. He speaks Arabic and Yoruba going by his function. He is a learned Islamic scholar, younger compared to Mufasiru. He reads in Arabic verses from the Holy Qur'aan at the request of Mufassir. With the survey carried out, $50 \%$ admit that Ajanansi is a Qur' aan reciter, $30 \%$ a spiritual commentator and $10 \%$ an interpreter (Appendix 1). By and large, Ajanansi helps Mufasiru during his religious lecture.

In fact Mufasiru according to Abu Ammenah Bilal Philips is 'a person who makes tafseer of the Qur'aan' (Philips 1997:83). Going by the definition of Mufassir by Philips that he is a maker of tafseer ${ }^{6}$, literally we can conclude that a Mufassir is an interpreter. Islamically, a Mufassir is more than an interpreter, he also engages in explaining the meanings of the Qur'aan. It goes in line with the data collected from the respondents to our questionnaires. Only $10 \%$ of the respondents are of the view that Mufasiru is an interpreter while 50\% agree that he explains and comments on the meaning of the Qur'aan. A higher percentage of 70 from the respondents say that Mufasiru is a preacher. There is no doubt about the preacher status of Mufassir known to 
spread the goodwill of Islam. But the public undermines the interpreter's status of Mufasiru with only $10 \%$ looking at him as that. This misconception of the public is mirrored in the data collated from the questionnaires. Going by his function, Mufassir is first an interpreter because he first interprets in Yoruba what Ajanansi reads for him in Arabic and then he goes further to explain. A Mufassir or Mufasiru (Yoruba pronunciation) is not just an interpreter. There is a similar respondents' reaction regarding tafseer with $10 \%$ of them looking at tafseer as interpretation of the Qur'aan and 50\% as commentary or explanation of the meaning of the Qur'aan (Appendix 1). The trend, if not checked, may interchange the meaning of Mufasiru, Arowasi and Ajanansi with time.

\section{Examples of Mufasiru: Sheik (Dr.) Alhaji Muhyideen Ajani Bello, Alhaji Sheik Buhari Musa and Alhaji Abd. Ganiyi Abd. Raheem Lafenwa}

The records of the three Islamic scholars are video cassettes digitally mastered. The title of Sheik Muhyideen A. Bello's track is Esan (Nemesis) (2007) while the ones of Sheik Buhari Musa are Eto Igbeyawo l'Aiye (Marriage) (2006), Eto Igbeyin fun Oku (Last respect for the Deceased) (2006), Iselu Iro (False politics) (2007). Alhaji Abd. Ganiyi Abd. Raheem Lafenwa is the third Islamic scholar in his Suratu-l Munafiqum (The Hypocrites) (2007).

Having carefully watched the VCD of the chosen Mufasiru in their preaching it is noted that they have different approach in the interpretation, explanation and commentary of the Islamic books written in Arabic. Their status of interpreter is carried out differently. Bello employed two Ajanansi while Musa is seen always assisted by only one Ajanansi. Lafenwa is with no Ajanansi. Yet they all are Mufasiru in the service of Islam playing the same role. The three Mufasiru employed no Arowasi whose function has been made redundant with the advancement in technology. The electronic speaker can be heard better than Arowasi who had only his voice for the job. Lafenwa combines the function of Ajanansi with the function of Mufasiru. He reads 
first in Arabic, then interprets and finally explains in Yoruba. Musa rather interprets what his only Ajanansi reads to him before any explanation. The VCD made the study clearer because one could see how the three characters relate during the preaching. The reading of the Arabic words and their interpretation by Ajanansi and Mufasiru are done in a musical way perhaps to attract and increase the level of concentration of the public.

\section{Conclusion}

Mufasiru, Ajanansi and Arowasi are three important personalities in Yoruba Muslim circles of Southwest Nigeria. Although, having been replaced by the electronic speaker, Arowasi is no longer needed, he is stil being addressed as the interpreter by the respondents narrowing the function of Mufasiru to just a commentator. Also Ajanansi, who is just a Qoori or a Qur'aan reciter, is sometimes regarded as an interpreter. Ajanansi and Arowasi are designed to assist Mufasiru in his job as interpreter and commentator. Mufasiru is not just an interpreter, but he is also a Qur'aan commentator.

\section{Notes}

1. Tafsiri is the Yoruba pronunciation of Tafsir.

2. Mufasiru is a Yoruba word metamorphosed from the Arabic word Mufassir to satisfy the Yoruba alignment of words and sound. Both have the same meaning but differ in spelling.

3. Hadith and Sunna: The tradition of the Holy Prophet, better known as Sunna or Hadith is the second and undoubtedly secondary source from which the teachings of Islam are drawn. The first source is the Qur' aan. The two words Hadith and Sunna are commonly used and differ in their significance. Hadith really means a story or a report, and so represents an account of what happened, whereas Sunna means a practice or a custom. Within the community of Islam, it is only natural these words come to be applied more particularly to matters related to the Prophet and to the customs followed by him 
and his immediate followers. Records were collected telling what the Prophet said and did and his reactions to things said and done in his presence (Sambo and Alimiyah 1976:32).

4. Observation can be defined as contact with the world through the use of the senses. ..Observation equips us with the material for thought, reflection, and judgment. What we experience by means of our senses-the sights, smells, touches, noises, and tastesprovides us with the data we require in order to survive. We report our observations in sentences called observation statements... The observation gives the raw data of the situation. We know the data because we have experienced it with our senses. We report it in a strictly simple sentence form. How we interpret observation material is quite another matter (Gerald, M. and Nancy, S, 1974:44-45).

5. Nasiat: Islamic public lecture (preaching).

6. There are different types of tafseer:

Tafseer of Qur'aan by Qur'aan: There are many places in the Qur'aan where questions are asked in order to catch the mind of the reader and subsequently answered to increase the impact of the concept in question... This self-explanatory process is referred to as tafseer of the Qur'aan by Qur'aan.

Tafseer of Qur'aan by the Sunnah: On many occasions, the prophet added further clarification to various verses of the Qur'aan. Allah has entrusted the job of explaining the Qur' aan to the Prophet. This trust was expressed in the Qur' aan in no uncertain terms. "I have revealed the Reminder (Qur' aan) to you (O Muhammad) so that you may explain to the people what has been revealed to them" (Surah an-Nahl 16: 44). "I have only revealed the Book to you (O Muhammad) in order that you clarify for them the things about which they differ (Surah an-Nahl 16:64).

Tafseer of Qur'aan by Aathaar: Whenever the sahaabah could not find the tafseer of a passage in the Qur'aan itself or in the Sunnah, they would use their own reasoning based on their knowledge of 
the contexts of the verses and the intricacies of the Arabic language in which the Qur' aan was revealed.

Tafseer of Qur'aan by Language: With the passage of time words took on new meanings and old meanings were lost; foreign words entered into the language; and vast sections of vocabulary fell into disuse. This natural process necessitated the explanation of some of the Qur'aanic words according to their literal and grammatical meanings.

Tafseer of Qur' aan by Opinion: Opinions based on a careful study of the first four steps can be considered valid as long as they do not contradict any of those steps.

\section{References}

O'Brien D. B., Cruise (1971) The Mourides of Senegal. The Political and Economic Organisation of an Islamic Brotherhood Oxford: Clarendon Press.

Gerald, M. and Nancy S. (1974) Patterns of Thinking, $2^{\text {nd }}$ edn, Belmont, California: Wadsworth Publishing Company, Inc., 1349.

Hodgkin, T. (1969) 'Islam and National movements in West Africa' in P. J. M. McEwan (ed.) Africa from early Times to 1800, London: Oxford University Press.

Knappert, J. (1970) 'Contribution from the study of loanwords to the cultural history of Africa' in David Dalby (ed.) Language and history in Africa, New York: Africana, 78-88.

Philips, Abu Ammenah B. (1997) The Methodology of Qur'anic Explanation, Shomolu, Lagos: Al-Waseelat Publishers, 1-344.

Sambo, M. B. and M. H. Alimiyah (1976) Hadith, Lagos: Islamic Publications Bureau, 1-139. 
Seymour, W. J. (1988) How can Africa survive, New York: Harper \& Row Publishers.

\section{Cassettes}

Bello, M. A. (2007) Esan (Nemesis), marketed and distributed by Alhaja Oriola Strore, Ibadan.

Lafenwa, G. R. (2007) Suratul-l-Munafiqun (The Hypocrites), marketed and distributed by Jislad Music, Lagos.

Musa, B. (2006) Eto Igbeyawo l'Aiye, marketed and distributed by Bablaje Music, Lagos.

Musa, B. (2006) Eto Igbeyin fun oku (Last respect for the Deceased), produced and marketed by Oracle Music Int'l, Lagos.

Musa, B. (2007) Iselu Iro (False politics), produced and marketed by Moh-Saheed Audio Visuals \& Comm., Ibadan.

\section{Table: Evaluation of Mufasiru and Tafsiri}

\begin{tabular}{|c|c|c|c|c|c|}
\hline & $\begin{array}{l}\text { (jur'aunic } \\
\text { mtcrpaces }\end{array}$ & $\begin{array}{l}\text { Qurtianic } \\
\text { Commenturor }\end{array}$ & $\begin{array}{l}\text { Istamis } \\
\text { Prencilace }\end{array}$ & $\begin{array}{l}\text { Quu'asmic } \\
\text { Reciler }\end{array}$ & $\begin{array}{l}\text { Repkat the } \\
\text { wards of } \\
\text { Muftssi }\end{array}$ \\
\hline Istasien & 10 & 50 & 70 & 0 & [t \\
\hline Ajanansi & 10 & 30 & 0 & 50 & In \\
\hline Anowesi & ओ & 0 & \langle & 0 & 70 \\
\hline
\end{tabular}

\begin{tabular}{|c|c|c|c|}
\hline & $\begin{array}{l}\text { Mererpetitian of } \\
\text { gurititn }\end{array}$ & 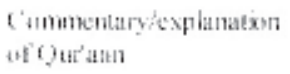 & Preaching of Istan \\
\hline Kafsini & Iin & 50 & 40 \\
\hline
\end{tabular}

